\title{
ÚJ MÓDSZEREK AZ ENDOSZKÓPIÁBAN
}

\section{NEW METHODS IN ENDOSCOPY}

\author{
Czakó László \\ $\mathrm{PhD}$, DSc, egyetemi tanár \\ Szegedi Tudományegyetem I. sz. Belgyógyászati Klinika, Szeged \\ czako.laszlo@med.u-szeged.hu
}

\begin{abstract}
ÖSSZEFOGLALÁS
Az endoszkópia a gasztroenterológia sikerágazata, az elmúlt évtizedekben jelentős fejlődésen ment át. A folyamat a fiberoszkópia bevezetésével kezdődött, és a videoendoszkópia, majd a kapszulás endoszkópia elterjedésével folytatódott. A kromoendoszkópia volt az endoszkópos képalkotást javító, a diagnosztikus hatékonyságot fokozó módszer. Ma már több, egyetlen gombnyomással müködtethető, felhasználóbarát, az endoszkópos képalkotás hatékonyságát fokozó technika (például: virtuális kromoendoszkópia, autofluoreszcens képalkotás) áll rendelkezésre. Terápiás endoszkópos beavatkozások (például endoszkópos szubmukóza-disszekció, rádiófrekvenciás abláció és teljes falvastagságú reszekció) segítségével korai malignus elváltozások távolíthatók el a gasztrointesztinális traktusból. Az endoszkópos ultrahang irányításával végzett terápiás beavatkozások (peripankreatikus folyadékok, epehólyag, epeutak drenálása, a plexus coeliakus blokádja, lokális tumorterápia) gyors elterjedése figyelhető meg. Ezen módszerek nemcsak a sebészeti beavatkozások alternatíváját jelentik, hanem sok területen helyettesítik is azt.
\end{abstract}

\section{ABSTRACT}

Extraordinary developments have been witnessed in the field of endoscopy over the past decades. This era began with the fiberoptic endoscope, it has now moved to the videoscope and, more recently, to the capsule endoscope. Chromoendoscopy was then introduced to improve imaging and aid diagnosis. In the last 10 years a series of 'push-button' technologies (e.g. narrowed-spectrum endoscopy and autofluorescence imaging) allowed advanced endoscopic imaging to be available in more simple ways. Confocal laser endomicroscopy allowed endoscopists to obtain 'in vivo histology'. Complex therapeutic procedures (e.g. endoscopic submucosal dissection, radiofrequency ablation and endoscopic full thickness resection) can now be performed to remove early malignant lesions in the gastrointestinal tract. Rapid development of interventional endoscopic ultrasound can nowadays be observed including drainage of peripancreatic collections, gallbladder and bile ducts, celiac plexus blocks, local tumor therapy. These techniques are competing and replacing surgical interventions. 
Kulcsszavak: kromoendoszkópia, virtuális kromoendoszkópia, autofluoreszcens képalkotás, konfokális lézer endomikroszkópia, kapszulás endoszkópia, spirálendoszkópia, endoszkópos szubmukóza-disszekció, rádiófrekvenciás abláció, elasztográfia, endoszkópos ultrahang

Keywords: chromoendoscopy, virtual chromoendoscopy, autofluorescence imaging, confocal laser endomicroscopy, capsule endoscopy, spiral enteroscopy, endoscopic submucosal dissection, radiofrequency ablation, elastography, endoscopic ultrasound

Az endoszkópia a gasztroenterológia legdinamikusabban fejlődő ágazata, alkalmazása alapvetően megváltoztatta az emésztőszervi betegségek kórismézését és kezelését. Az első endoszkópot 1867-ben fejlesztették ki, ami még egy merev cső volt, ezért kezdetben kardnyelőkön tesztelték (1AB ábra). A hajlítható üvegszáloptikás müszerek (fiberoszkópia), majd a képtovábbítást lehetővé tevő analóg képfeldolgozó chip (charge-coupled device, CCD) alkalmazásával a videoendoszkópia kifejlesztése révén jutunk el a mai endoszkópokhoz ( $1 C$ ábra), ahol a munkacsatornán bevezetett tartozékok segítségével további diagnosztikus (például mintavétel biopsziás csípővel) és terápiás (polipeltávolítás hurokkal) végezhető (1D ábra).

A

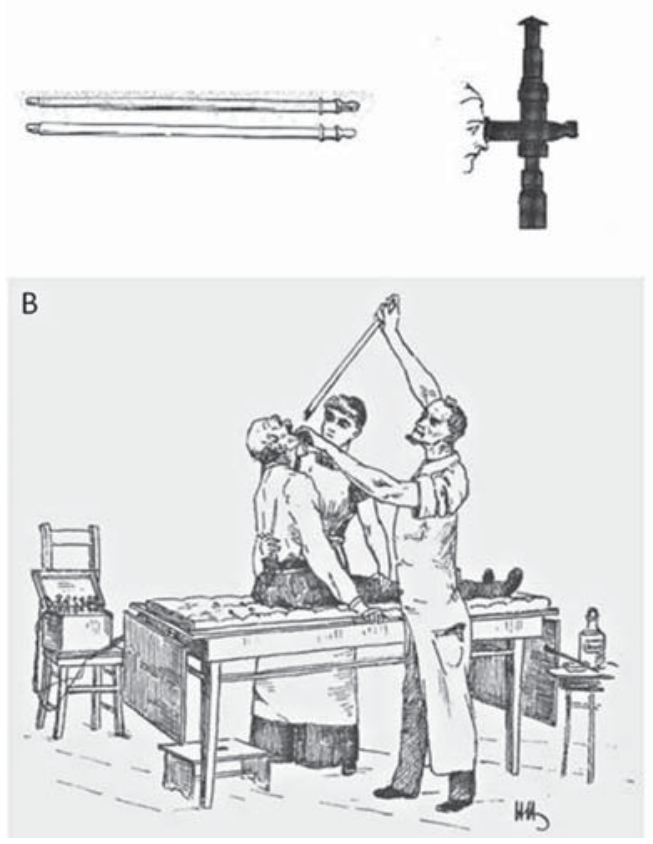

C

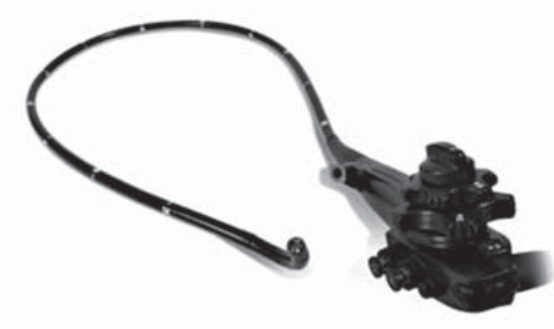

D

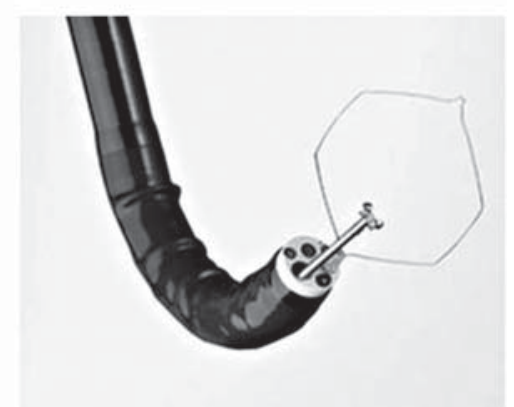

1. ábra. Merev endoszkóp alkalmazása (A, B). Videoendoszkóp (C) munkacsatornájában biopsziás csípő és polipektómiás hurok (D) 


\section{DIAGNÓZIST ELŐSEGITŐ TECHNIKÁK}

Az endoszkópia lényege, hogy a gasztrointesztinális traktus nyálkahártyájáról minél pontosabb és részletgazdagabb képet tudjunk előállítani, hiszen ez az elöfeltétele a daganatok korai, még gyógyítható stádiumban történő felismerésének. Az endoszkópos vizsgálatok során használatos intravitális festési eljárásokkal (kromoendoszkópia) fokozható a kontrasztosság, felerősíthetőek a nyálkahártya apró szerkezeti eltérései, így felismerhetővé válnak olyan nyálkahártya-eltérések, melyek szabad szemmel nem észlelhetők. Mindez elősegíti a korai malignus elváltozások detektálását (2. ábra), a daganatos terület körülrajzolása révén segít annak eldöntésében, hogy az elváltozás endoszkóposan eltávolítható-e, valamint irányítja a célzott szöveti mintavételt (Czakó et al., 2002). Gyulladásos bélbetegnél az emelkedett vastagbéldaganat rizikója miatt végzett ellenőrző kolonoszkópiák során a kromoendoszkópia segít a biopsziák helyének kijelölésében és a mintavétel hatékonyságának a növelésében. Az egy cm-nél kisebb vastagbélpolipok hisztológiai dignitását kromoendoszkópia segítségével előre megjósolhatjuk, ami támpontot ad a betegek ellenőrzéséhez.

A legújabb képalkotó technikák - a kromoendoszkópia kedvező eredményei alapján - arra irányulnak, hogy a látott elváltozásokról optikai módszerek segítségével mind több, már a szövettani eredményt közelítő információhoz jussunk. Ezeket a módszereket virtuális/digitális kromoendoszkópiának nevezzük (East et al., 2016). Kifejlesztésük a három vezető japán endoszkópos cég (Olympus, Fujifilm, Pentax) kutatásainak eredménye. Az első és ezért ma a legelterjedtebb módszer a narrow band imaging (NBI) technika. Az NBI során szürő segítségével a kibocsátott fény
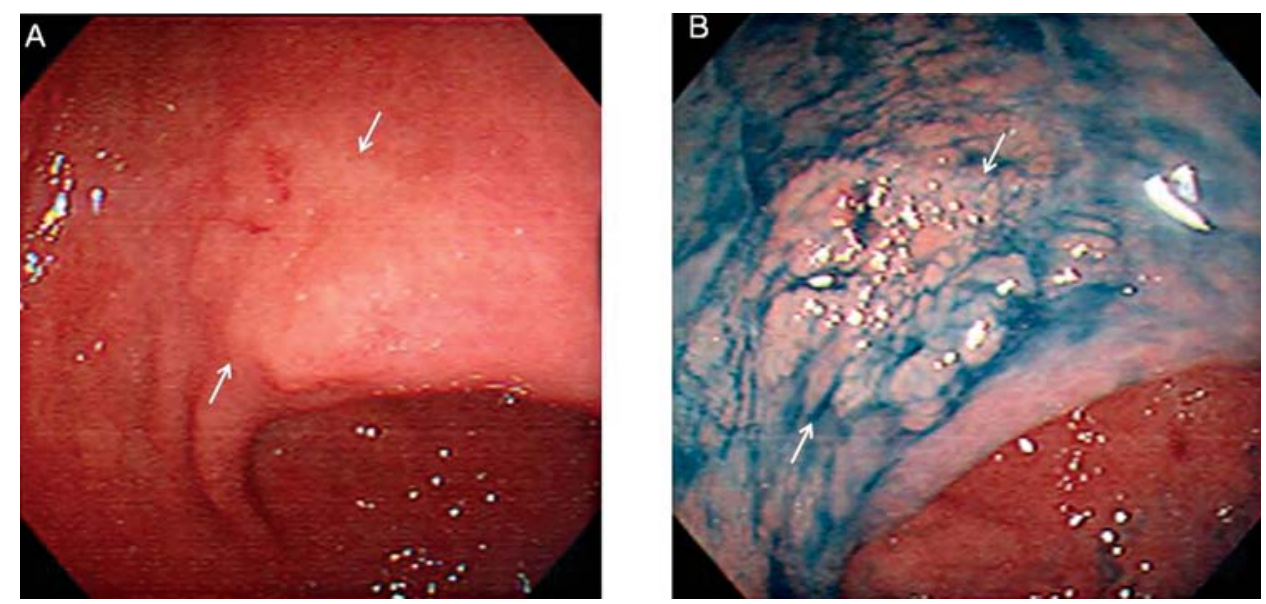

2. ábra. Lapos gyomorpolip (korai karcinóma) a rutin endoszkópia (A) és a kromoendoszkópia során (B) 


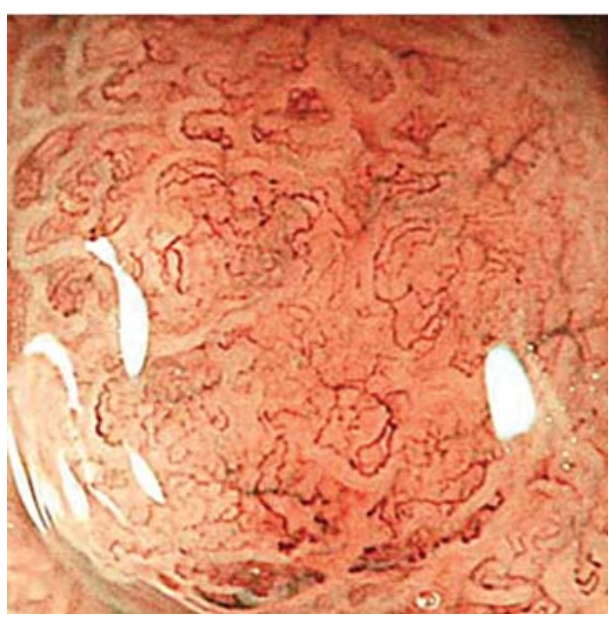

3. ábra. Narrow band imaging technika, nagyított felvétel. A nyálkahártya kapillárisok irregularitása korai gyomorkarcinómára utal

spektrumát szükítik 415-540 nm-re, a vörös fénykomponenst kiiktatják, s az így szürt fény nem hatol olyan mélyen a szövetekbe, és a vér hemoglobinja is jobban abszorbeálja, mint a környező szövetek. Mindezek eredményeképp a nyálkahártya kapillárisok kontrasztosabbak, a felszíni struktúrák részletgazdagabbak lesznek (3. ábra). Mivel az egyes elváltozások jellegzetes érstruktúrával bírnak, így az NBI növeli a diagnosztikus pontosságot, a korai karcinómák felismerhetőségét, másrészt a terápiás beavatkozáshoz pontosabban jelöli ki az elváltozás határait. A FICE(Fujinon Intelligent ChromoEndoscop) és az I-SCAN- (i-Scan digital contrast) technika során a már visszavert fényt alakítják szürőkkel, majd a processzor algoritmusok segítségével hullámhosszanként pixelről pixelre rekonstruálják a képet (post-processing technology). A módszer alkalmazásával az elváltozások kontrasztosabbá válnak, ami pontosabbá teszi az endoszkópos diagnózist. Mindhárom virtuális kromoendoszkópia rendszer - a hagyományos kromoendoszkópiával szemben - vizsgálat közben egyetlen gombnyomással aktiválható (push-button technikák), tehát felhasználóbarát.

A hagyományos kromoendoszkópia és a virtuális kromoendoszkópia a fehér fénnyel már felismert elváltozások pontosabb jellemzésével segítik a diagnózist. Az autofluoreszcens képalkotás során viszont a releváns elváltozásokról kapunk több információt (red flag technology). A testünkben előforduló fluorofór molekulák rövid hullámhosszúságú fény hatására fluoreszkálnak, azaz nagyobb hullámhosszúságú fényt bocsátanak ki. Az autofluoreszcens képalkotás során szürő segítségével a fluoreszcenciát generáló hullámhosszúságú fénnyel világítják meg a nyálkahártyát, és egy további CCD-érzékelő segítségével valós időben detektálják a fluoreszcenciát. Az egészséges és daganatos szövetek eltérő vastagságuk, vérátáramlásuk és a bennük lévő fluoroform anyagok különbözősége miatt más színben világítanak. A módszer magas szenzitivitása (92\%) meggyőző, azonban gyulladásos elváltozások is hasonló autoflureszcenciás mintát adnak, mint a daganat, így a módszer specificitása meglehetősen alacsony (28\%).

A konfokális lézer endomikroszkópia segítségével az endoszkópos képalkotás nagyítását 1000-szeres értékig tudjuk fokozni, így in vivo körülmények között a valós időben tudjuk a nyálkahártya sejtjeit, sejtalkotóit vizsgálni, s ezáltal „virtuális biopsziát" végezni. A módszer során az endoszkóp munkacsatornáján vezetik 
le a konfokális mikroszkóp minipróbot. A megvilágításhoz 488 nm-es lézerfényt használnak, és egy $550 \times 550 \mu \mathrm{m}$ nagyságú terület $250 \mu \mathrm{m}$ mélységben, $1 \mu \mathrm{m}$-nél kisebb felbontással vizsgálható át. A vizsgálathoz fluoreszcein kontrasztanyag intravénás adása szükséges.

A vékonybél az endoszkópos képalkotás számára sokáig megközelíthetetlen volt. A technika fejlődése és a miniatürizálás tette lehetővé a kapszulás endoszkópia megszületését (Rondonotti et al., 2018). A vitamintabletta méretü kapszula (4A. ábra) tartalmazza a fényforrást, a kamerát, az elemet és a kommunikációs modult. A lenyelt kapszula természetes úton végighalad az emésztőrendszeren, és másodpercenként két képet készít a vékonybél nyálkahártyájáról. A képeket rádióhullámon keresztül juttatja ki a hasfalon elhelyezett érzékelőkön át egy kis méretü, övvel rögzített készülékbe, ahol a képek tárolódnak. Ezek a képek kerülnek számítógépbe beolvasásra és értékelésre $(4 B, C$ ábra). A vizsgálat végén az egyszer használatos kapszula a széklettel távozik a szervezetből. A kapszulás endoszkópia legfontosabb indikációi az obskúrus gasztrointesztinális vérzés, a vékonybél Crohn-betegsége, a vékonybél tumorgyanúja, a polipózis szindrómák
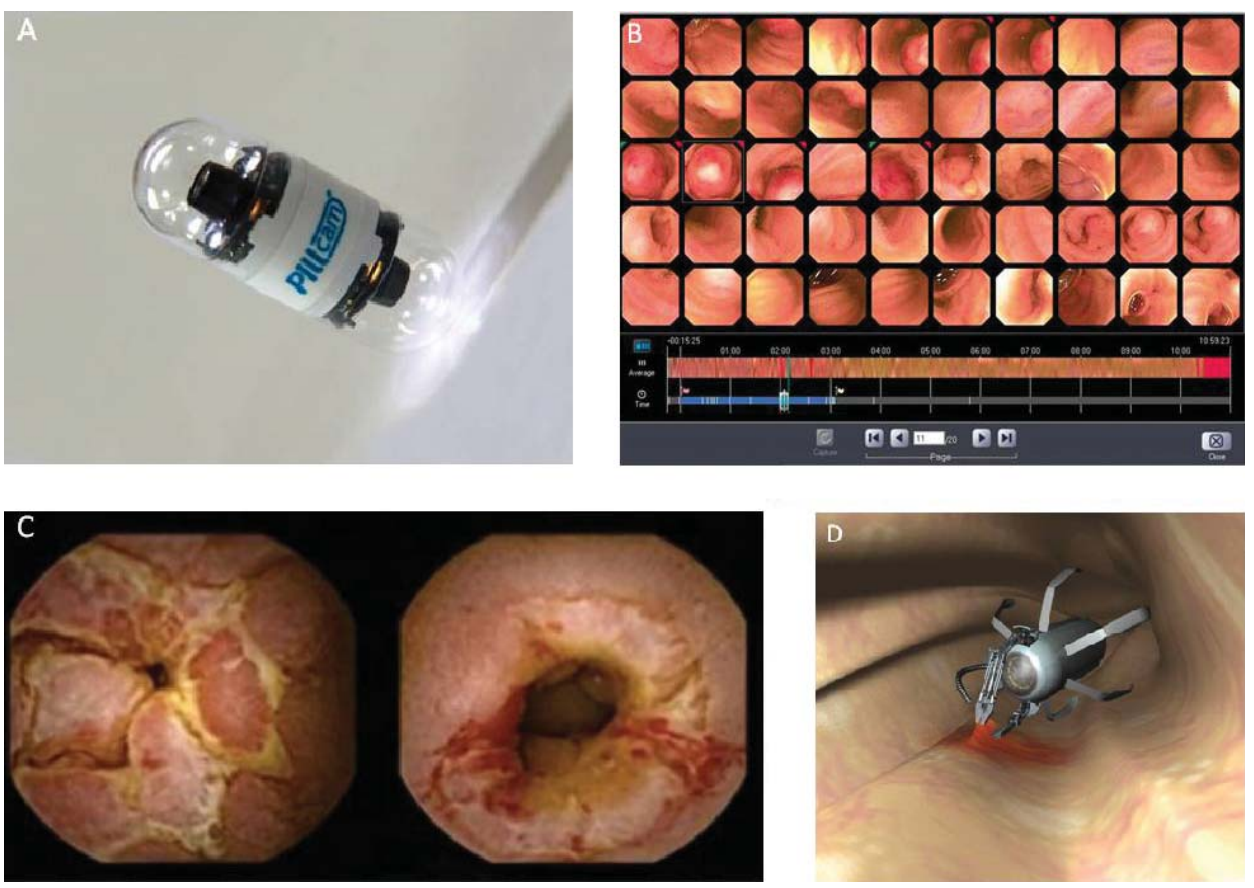

4. ábra. Endoszkópiás vizsgálathoz használt kapszula (A). A kapszula által készített képek beolvasása a számítógépen (B). Crohn-betegség okozta vékonybél-szűkület igazolása kapszulás endoszkópia során (C). A jövő kapszulája, amely irányítható, és mintát is tud venni a nyálkahártyából (D) 
és a refrakter cöliákia terápiájának követése. A jövőt az irányítható microrobot kapszula jelenti, amely mintavételre, a daganatos nyálkahártya kivágására és gyógyszerek célba juttatására is alkalmas (Saurin et al., 2016) (4D. ábra).
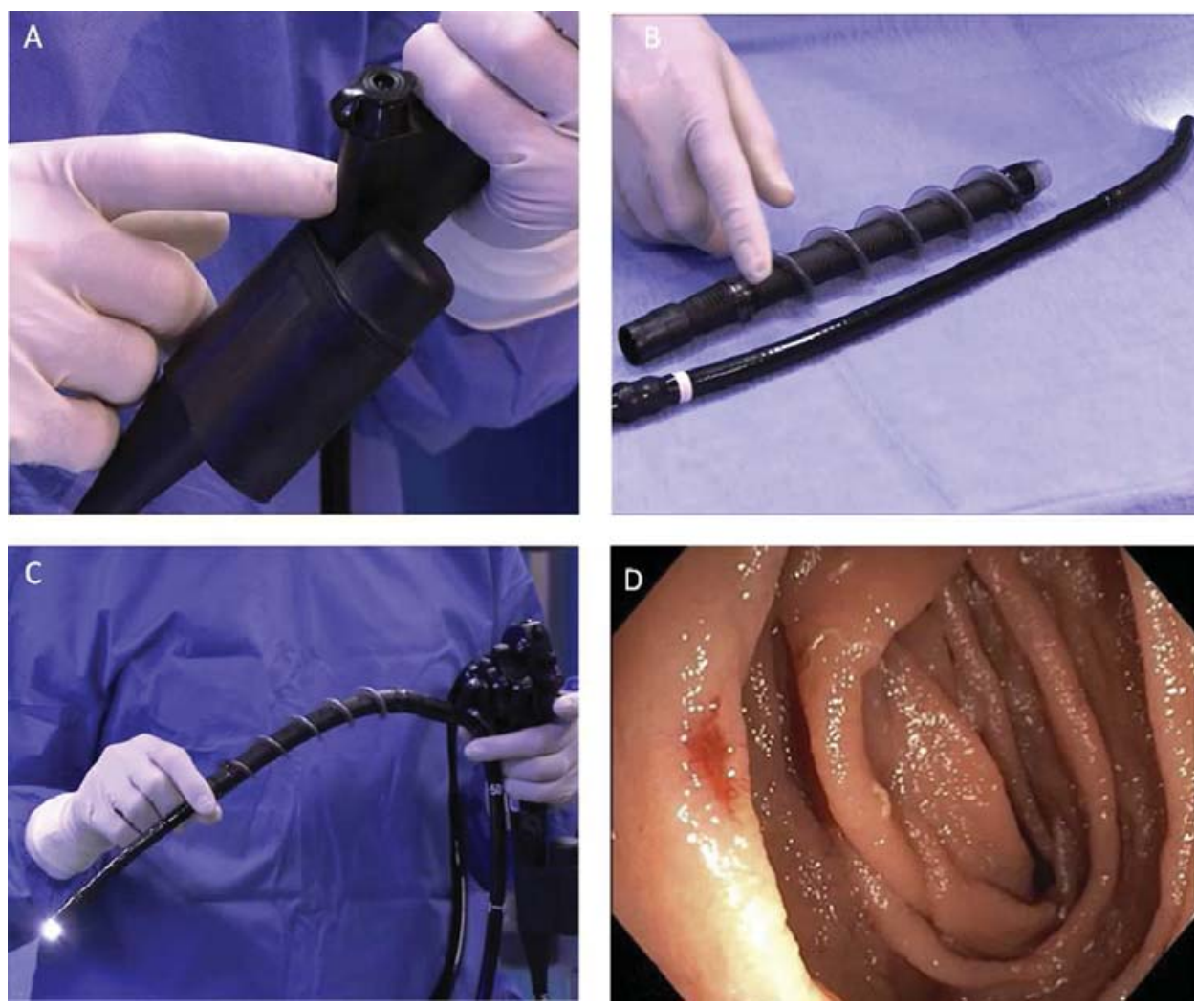

5. ábra. Motorizált spirálendoszkópia. Az endoszkóp kezelö felőli végébe épített motor bekapcsolásával (A) forgatható az endoszkóp beteg felőli végére felcsavarható spirálisan körbefutó billentyü (B, C). Vérzést okozó vékonybél angiodiszplázia kórismézése (D)

A kapszulás endoszkópia pusztán diagnosztikus vizsgálat. A vékonybél területén a megtekintés mellett a mintavételt és a terápiás eljárások kivitelezését az enteroszkópia teszi lehetővé. Az idei évben jelent meg a motorizált spirálendoszkópia technika (Mans et al., 2018). Az endoszkóp kezelő felóli végébe épített motor bekapcsolásával forgatható az endoszkóp beteg felöli végére felcsavarható spirálisan körbefutó billentyü (5. ábra). A spirális billentyü óramutató irányában történő forgatása biztosítja az endoszkóp vékonybélben történő tovahaladását. A motorizált technika alkalmazása jelentősen felgyorsítja a vizsgálatot, és kiváltja a második vizsgálót, így az enteroszkópia egy endoszkópos alkalmazásával elvégezhető. 


\section{DAGANATOK MINIMÁL INVAZÍV ELTÁVOLÍTÁSA (ESD, EFTR, RFA)}

Az endoszkópos reszekciós technikák segítségével korai malignus elváltozásokat tudunk minimális invazivitással, a sebészi reszekcióval szemben a szerv megkímélésével eltávolítani a gasztrointesztinális traktus területéről (Czakó, 2015; Szalóki et al., 2008). Új technika az endoszkópos szubmukóza-disszekció (ESD), ami a korábbinál lényegesen nagyobb felszíni kiterjedésü, felületes nyálkahártya daganatok egy darabban történő eltávolítását teszi lehetővé speciális endoszkópos kések alkalmazásával (Mavrogenis et al., 2017) (6. ábra). Az ESD kevesebb szövődménnyel és rövidebb kórházi tartózkodással jár, olcsóbb, és jobb életminőséget eredményez a sebészi eltávolítással szemben.

A bélfal mélyebb rétegeibe terjedő, vagy hegesedést miatt nem előemelhető, vagy nehezen elérhető helyen lévő daganatokat korábban endoszkóposan nem, hanem csak sebészi úton lehetett eltávolítani. Egy ötletes módszer lehetővé teszi a vastagbél teljes
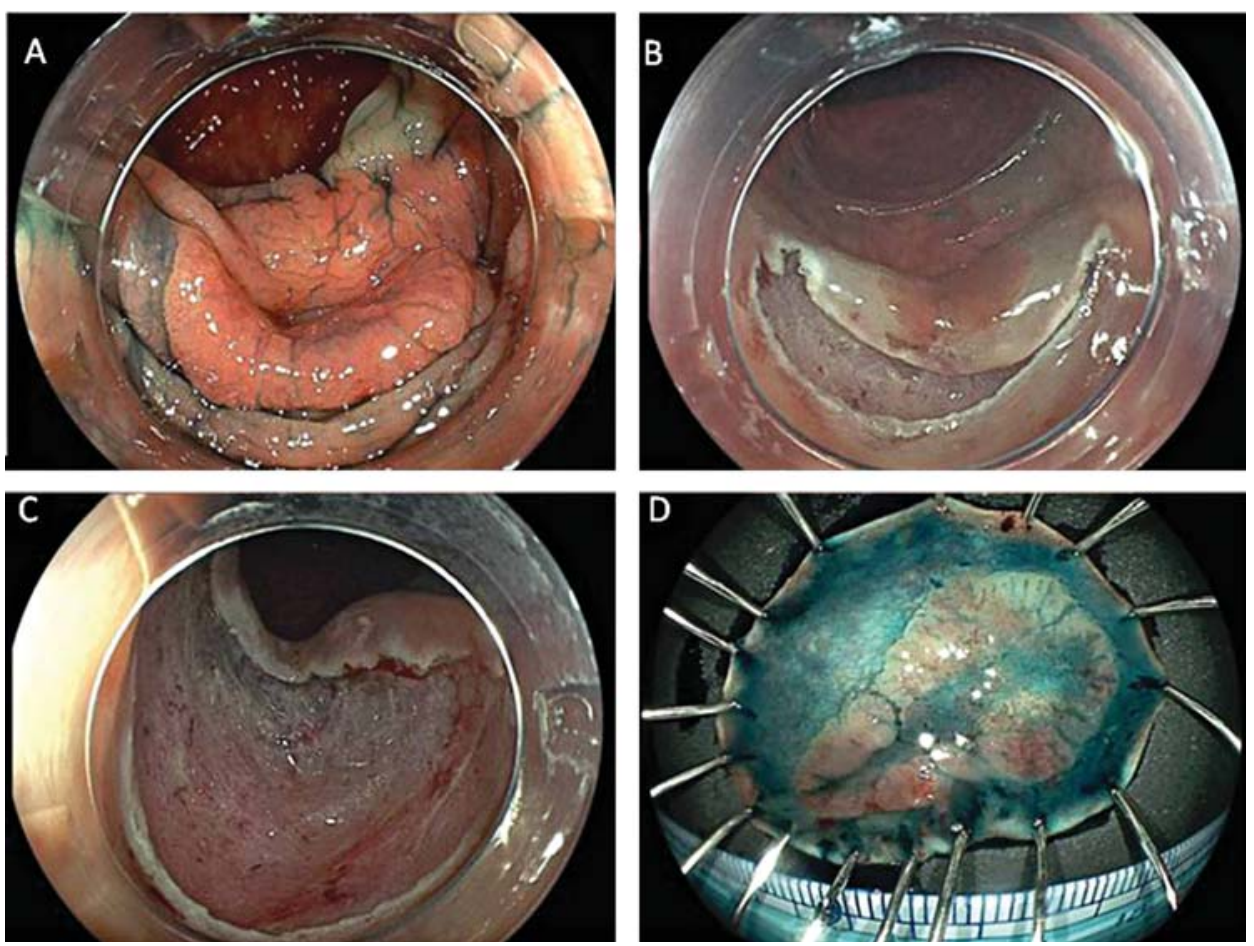

6. ábra. Endoszkópos szubmukóza-disszekció. Oldalirányba terjedő, lapos vastagbél daganat (A). Elöször a daganat körül körkörösen bemetsszük a nyálkahártyát (B), majd a speciális kések segítségével leválasztjuk az elváltozást a bélfal izomrétegéről (C). A parafinlapra felgombostüzött eltávolított daganat (D) 


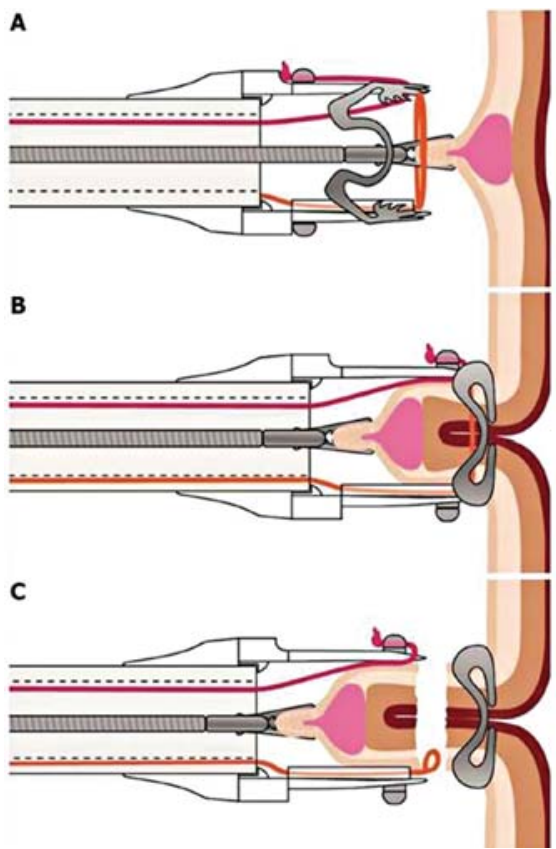

7. ábra. Endoscopic full thickness resection. A bélfali elváltozást csípővel megragadva behúzzuk az endoszkóp végére felhelyezett müanyag toldalékba úgy, hogy a teljes vastagbélfal duplikátumot alkosson (A).

A klippet (medvecsapda) lezárjuk az elváltozás alatt (B), majd felette a toldalékba épített hurokkal az elváltozást levágjuk (C) falvastagságának körülírt endoszkópos eltávolitását (endoscopic full thickness resection, EFTR) (Rajan-Wong Kee Song, 2018). Az eljárás lényege, hogy a bélfal reszekciója után annak folytonosságát egy kicsinyített medvecsapda felhelyezésével biztosítják (7. ábra).

A Barrett-nyelőcső a refluxbetegség szövődményeként a nyelöcső gyomorszáj feletti részén kialakuló premalignus állapot, amely hajlamosít a nyelőcső karcinóma kialakulására. Amennyiben az endoszkópos vizsgálat során a területről vett minta szövettani vizsgálata a daganatos átalakulás előzetes jeleit (diszplázia) mutatja, az érintett nyálkahártya endoszkópos eltávolítása javasolt. Ennek leghatékonyabb módszere a rádiófrekvenciás ablácó (RFA) (Shaheen et al., 2009). A felfújható ballon felszínén elhelyezkedő elektródát az érintett nyálkahártya-felületre illesztjük, és rövid ideig $(<300 \mathrm{~ms}) 300 \mathrm{Watt}$ energiájú áramot használva elroncsoljuk a felszíni hámot és az alatta lévő izomréteget (8. ábra).

\section{ENDOSZKÓPOS ULTRAHANG}

Az endoszkópos ultrahang- (EUH) vizsgálat az endoszkópos és ultrahangos képalkotás kombinálásából jött létre. Megszületését az inspirálta, hogy a hasnyálmirigy (pankreász) retroperitoneális helyzete miatt a képalkotó vizsgálatok számára nehezen megközelíthető szerv. Úgy gondolták, hogy az EUH során a gyomor, illetve a duodenum lumenéből a zavaró bélgázok és hasi zsírszövet kiküszöbölésével a hasnyálmirigy közelsége miatt nagyobb ultrahang-frekvencia alkalmazásával eredményesebben vizsgálható. Ma az EUH az endoszkópia legdinamikusabban fejlődő területe.

Az elasztográfia az elváltozások további karakterizálását segítő technika. A vizsgálat alapja az, hogy az ultrahangos fejjel a célszerv kompressziója kemény (általában malignus) szövet esetén kisebb feszültséget eredményez, mint puha 

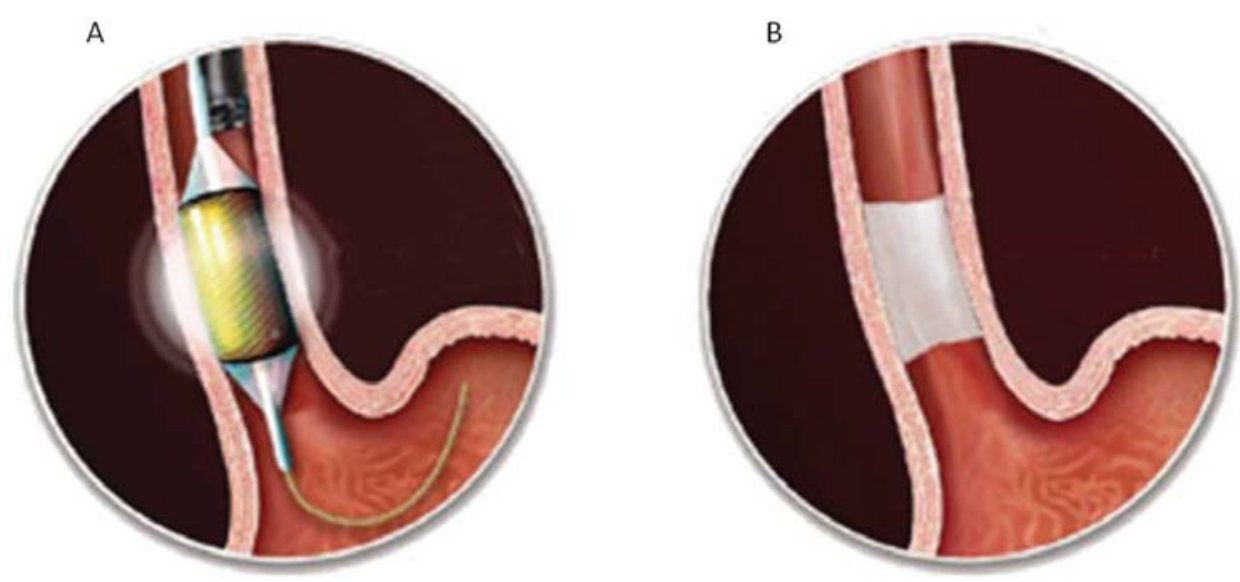

8. ábra. Barrett-nyelőcső rádiófrekvenciás ablációja. A felszínén elektródokat tartalmazó felfújható ballont vezetődróton az elváltozás magasságában pozicionáljuk (A), és rövid ideig alkalmazott áramleadással égetjük le a felszíni hámot (B)

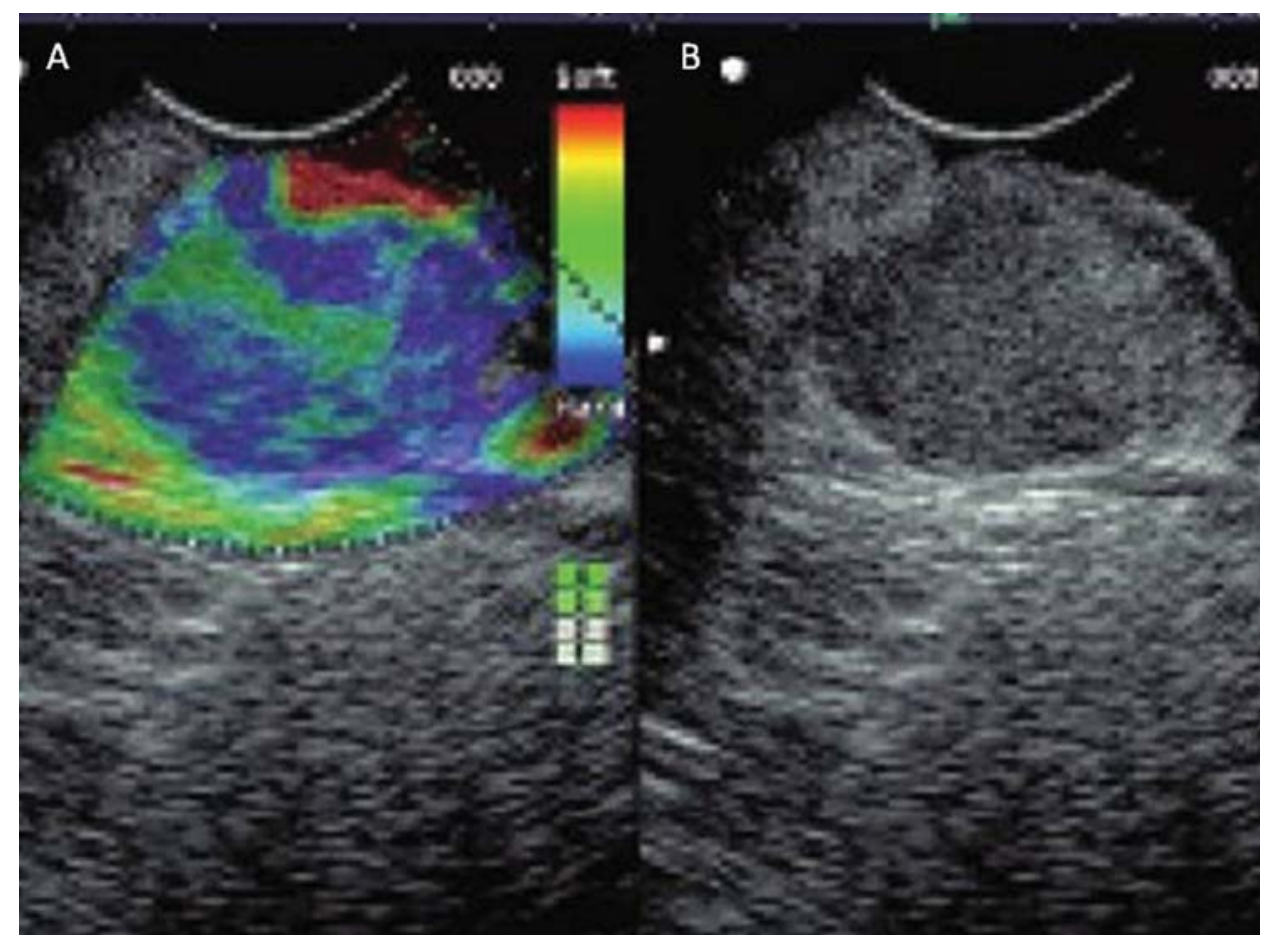

9. ábra. Pankreász EUH során végzett elasztográfia. A vizsgálat során az elváltozáson (B) belül a kemény, malignus és a puha, benignus területek eltérő színben ábrázolódnak (A), ami segíti az elkülönítésüket és a célzott mintavételt 
(általában benignus) szövetek esetén (9. ábra). Így az elasztográfia megmutatja, hogy mely területek a valószínüleg malignusak, és ezáltal irányítja a vékonytü aspirációs mintavételt (Friedberg-Lachter, 2017).

Az EUH az utóbbi évtizedben minimálisan invazív módon terápiát is képes nyújtani, és ezáltal sebészi vagy radiológiai beavatkozásokat kiváltani, mivel azoknál eredményesebb, kevesebb szövődménnyel jár vagy költséghatékonyabb (Venkatachalapathy-Nayar, 2017). Az akut hasnyálmirigy-gyulladás következtében kialakuló peripankreatikus folyadékgyülemek (pszeudociszta és walled-off necrosis) kezelésében randomizált vizsgálatok eredményei alapján az EUH-vezérelt drenázs az első-
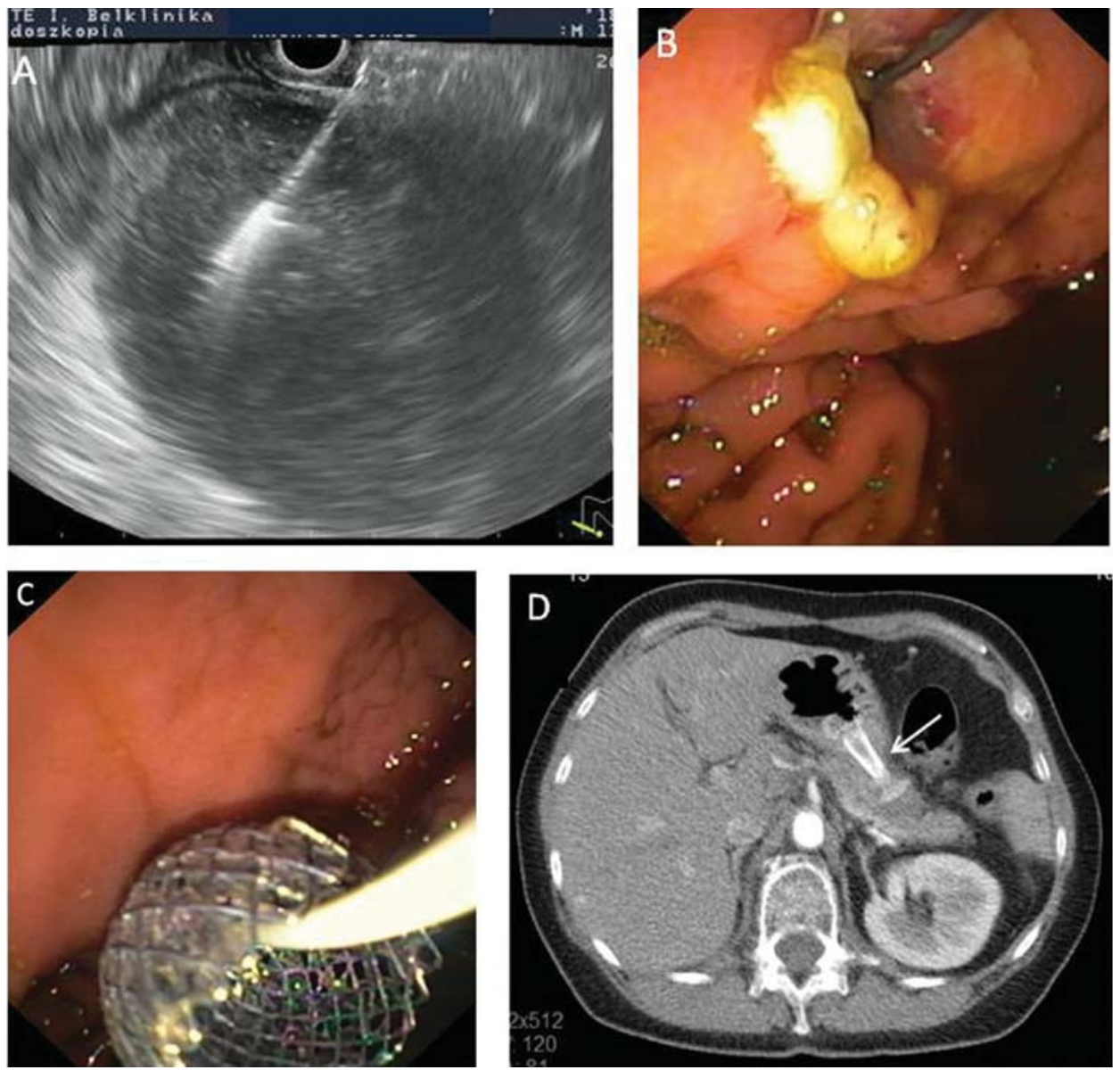

10. ábra. Endoszkópos ultrahangvezérelt walled-off pankreász nekrózis (WOPN) drenázs. Endoszkópos ultrahangvezérléssel, a legrövidebb és érmentes útvonalon tủvel szúrjuk meg a WOPN-t (A). Vezetődróton ballonnal a fisztulajáratot feltágítjuk (B), és egy fedett öntáguló fémsztent behelyezésével biztosítunk tartós összeköttetést a gyomor és a WOPN között (C, D) 
ként választandó technika, mert hatékonyabb, mint a korábban végzett sebészi vagy perkután drenázs (van Brunschot et al., 2018). AZ EUH-drenázs előnye, hogy a gyomor lumenében bedomborodást nem okozó folyadékgyülemek is jól ábrázolhatók, kiválasztható a legrövidebb szúrási útvonal, elkerülhetők a területen futó erek. A beavatkozás során vékony tűvel fisztulajáratot hozunk létre a gyomor ürege és a folyadékgyülem között, amit vezetődróton feltágítunk, majd sztentet vezetünk a drenázs fenntartása céljából a folyadékgyülembe (10. ábra). Ugyanezen technikát alkalmazva 1) epeúti elzáródás esetén a sztent epeútba ültetésével és az epe gyomorba/nyombélbe vezetésével a sárgaságot tudjuk megszüntetni; 2) epehólyag-gyulladás esetén az epehólyagot az emésztőrendszerbe

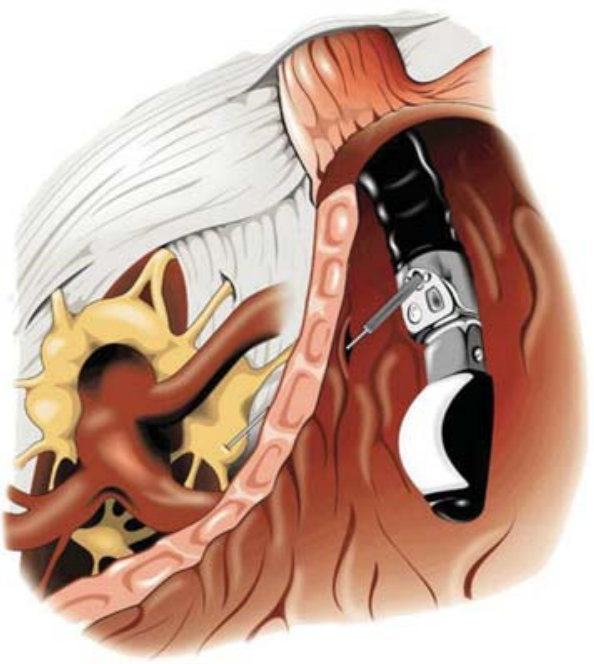

11. ábra. Ganglion cöliákum neurolízis. Endoszkópos ultrahang-ellenőrzés mellett injektált tömény alkohollal roncsoljuk a fájdalomérzetet továbbító idegközpontot a gyomor mögött drenálva gyógyítjuk meg a gyulladást; 3) a gyomorkimenet elzáródásakor a gyomor és a vékonybél között tudunk összeköttetést létrehozni, és tudjuk biztosítani a beteg táplálását.

Az EUH munkacsatornáján levezetett tűn keresztül tetszés szerinti hatóanyagot tudunk célzottan a kívánt területre juttatni. Hasi daganatos betegségek okozta, más módszerrel nem csillapítható fájdalom esetén eredményesen használható a gyomor mögött elhelyezkedő, a fájdalomérzetet továbbító ganglion cöliákum roncsolása. A vizsgálat során UH-ellenőrzés mellett tudjuk közvetlenül a ganglionba vezetni a tünket, és tömény alkohol beadásával elroncsolni azt (11. ábra). Ugyanezen technikával közvetlenül a daganatba adott citosztatikummal tudjuk a daganatot roncsolni. Így nagy hatóanyag-koncentráció érhető el a tumorban, míg a vérbeli hatóanyagszint elhanyagolható, így nem kell számolni a szisztémás mellékhatásokkal. Speciális tüket alkalmazva és azokat EUH-vezérelten a hasnyálmirigy daganatba juttatva $r a ́$ diófrekvenciás abláció vagy krioterápia végezhetö, ahol az extrém magas, illetve alacsony hőmérséklet révén szisztémás mellékhatások nélkül roncsolható a daganat.

\section{IRODALOM}

Bene L.: Az endoszkópos vizsgálatok technikai és személyi feltételei. In: Bene L. - Gyökeres T. Pap Á. (szerk.): Emésztőszervi endoszkópia. Budapest: Medicina Könyvkiadó, 33-43. 
van Brunschot, S. - van Grinsven, J. - van Santvoort, H. C. (2018): Endoscopic or Surgical Step-up Approach for Infected Necrotising Pancreatitis: A Multicentre Randomised Trial. The Lancet, 6, 391(10115), 51-58. DOI: 10.1016/S0140-6736(17)32404-2, https://bit.ly/2TMCjyZ

Czakó L. (2015): Endoszkópos mucosa reszekció, endoszkópos submucosa disszekció. In: Bene L. - Gyökeres T. - Pap Á. (szerk.): Emésztőszervi endoszkópia. Budapest: Medicina Könyvkiadó, 169-177.

Czakó L. - Szalóki T. - Lonovics J. (2002): A japán endoszkópos technika. Magyar Belorvosi Archívum, 55, 29-35.

East, J. E. - Vleugels, J. L. - Roelandt, P. et al. (2016): Advanced Endoscopic Imaging: European Society of Gastrointestinal Endoscopy (ESGE) Technology Review. Endoscopy, 48, 11, 10291045. DOI: $10.1055 / \mathrm{s}-0042-118087$, https://www.researchgate.net/publication/308926874_Advanced_endoscopic_imaging_European_Society_of_Gastrointestinal_Endoscopy_ESGE_ Technology_Review

Friedberg, S. R. - Lachter, J. (2017): Endoscopic Ultrasound: Current Roles and Future Directions. World Journal of Gastrointestinal Endoscopy, 16, 9, 10, 499-505. DOI: 10.4253/wjge.v9.i10.499

Mans, L. - Arvanitakis, M. - Neuhaus, H. et al. (2018): Motorized Spiral Enteroscopy for Occult Bleeding. Digestive Diseases, 26:1-3. DOI: 10.1159/000488479, https:/www.karger.com/Article/FullText/488479

Mavrogenis, G. - Hochberger, J. - Deprez, P. et al. (2017): Technological Review on Endoscopic Submucosal Dissection: Available Equipment, Recent Developments and Emerging Techniques. Scandinavian Journal of Gastroenterology, 52, 4, 486-498. DOI: 10.1080/00365521.2016.1271996, https://www.researchgate.net/publication/311465253_Technological_review_on_endoscopic_submucosal_dissection_available_equipment_recent_developments_and_emerging_techniques

Rajan, E. - Wong Kee Song, L. M. (2018): Endoscopic Full Thickness Resection. Gastroenterology, 154, 7, 1925-1937.e2. DOI: 10.1053/j.gastro.2018.02.020

Rondonotti, E. - Spada, C. - Adler, S. et al. (2018): Small-bowel Capsule Endoscopy and Device-assisted, Enteroscopy for Diagnosis and Treatment of Small-bowel Disorders: European Society of Gastrointestinal Endoscopy (ESGE) Technical Review. Endoscopy, 50, 4, 423-446. DOI: 10.1055/a-0576-0566, https://www.esge.com/assets/downloads/pdfs/guidelines/2018_a_0576_0566.pdf

Saurin, J. C. - Beneche, N. - Chambon, C. et al. (2016): Challenges and Future of Wireless Capsule Endoscopy. Clinical Endoscopy, 49, 1, 26-29. DOI: 10.5946/ce.2016.49.1.26, https://www.ncbi. nlm.nih.gov/pmc/articles/PMC4743730/

Shaheen, N. J. - Sharma, P. - Overholt, B. F. et al. (2009): Radiofrequency Ablation in Barrett's Esophagus with Dysplasia. The New England Journal of Medicine, 360, 2277-2288. DOI: 10.1056/NEJMoa0808145, https://www.nejm.org/doi/full/10.1056/nejmoa0808145

Szalóki T. - Tóth V. - Németh I. et al. (2008): Endoscopic Mucosal Resection: Not Only Therapeutic, But a Diagnostic Procedure for Sessile Gastric Polyps. Journal of Gastroenterology and Hepatology, 23, 4, 551-555. DOI: 10.1111/j.1440-1746.2007.05247.x, http://www.academia. edu/7072751/Endoscopic_mucosal_resection_Not_only_therapeutic_but_a_diagnostic_procedure_for_sessile_gastric_polyps

Venkatachalapathy, S. - Nayar, M. K. (2017): Therapeutic Endoscopic Ultrasound. Frontline Gastroenterology, 8, 119-123. DOI:10.1136/flgastro-2016-100774, https://fg.bmj.com/content $/ 8 / 2 / 119$ 